\title{
Targeting nicotine addiction: the possibility of a therapeutic vaccine
}

\author{
This article was published in the following Dove Press journal: \\ Drug Design, Development and Therapy \\ I5 April 201 I \\ Number of times this article has been viewed
}

\section{José Juan Escobar-Chávez' Clara Luisa Domínguez- Delgado ${ }^{2}$ Isabel Marlen Rodríguez- Cruz $^{2}$}

'Unidad de Investigación

Multidisciplinaria, Facultad de Estudios Superiores Cuautitlán-Universidad Nacional Autónoma de México, Cuautitlán Izcalli, Estado de México, México; ${ }^{2}$ División de Estudios de Posgrado (Tecnología Farmacéutica), Facultad de Estudios Superiores Cuautitlán-Universidad Nacional Autónoma de México, Cuautitlán Izcalli, Estado de México, México
Correspondence: José Juan Escobar-Chávez Unidad de Investigación Multidisciplinaria. Laboratorio 12. Facultad de Estudios Superiores Cuautitlán-Universidad Nacional Autónoma de México. Km 2.5 Carretera Cuautitlán-Teoloyucan, San Sebastián Xhala, Cuautitlán Izcalli, Estado de México, MéxicoCP. 547/4 Tel +525558724094 Fax +52 5556 I5 7077 Email josejuanescobar@gmail.com

\begin{abstract}
Cigarette smoking is the primary cause of lung cancer, cardiovascular diseases, reproductive disorders, and delayed wound healing all over the world. The goals of smoking cessation are both to reduce health risks and to improve quality of life. The development of novel and more effective medications for smoking cessation is crucial in the treatment of nicotine dependence. Currently, first-line smoking cessation therapies include nicotine replacement products and bupropion. The partial nicotinic receptor agonist, varenicline, has recently been approved by the US Food and Drug Administration (FDA) for smoking cessation. Clonidine and nortriptyline have demonstrated some efficacy, but side effects may limit their use to second-line treatment products. Other therapeutic drugs that are under development include rimonabant, mecamylamine, monoamine oxidase inhibitors, and dopamine D3 receptor antagonists. Nicotine vaccines are among newer products seeking approval from the FDA. Antidrug vaccines are irreversible, provide protection over years and need booster injections far beyond the critical phase of acute withdrawal symptoms. Interacting with the drug in the blood rather than with a receptor in the brain, the vaccines are free of side effects due to central interaction. For drugs like nicotine, which interacts with different types of receptors in many organs, this is a further advantage. Three anti-nicotine vaccines are today in an advanced stage of clinical evaluation. Results show that the efficiency of the vaccines is directly related to the antibody levels, a fact which will help to optimize the vaccine effect. The vaccines are expected to appear on the market between 2011 and 2012.
\end{abstract}

Keywords: nicotine addiction, nicotine vaccine, smoking cessation

\section{Introduction}

Tobacco smoking is the number one cause of premature death in developed countries. ${ }^{1}$ It is responsible for approximately 400,000 premature deaths per year in the United States alone, ${ }^{2}$ and around 4.9 million deaths per year worldwide, or $8.8 \%$ of all deaths globally. ${ }^{3}$ Worldwide, more than 1 billion adults are regular tobacco smokers, ${ }^{4}$ and most of them use manufactured cigarettes. ${ }^{5}$ Smoking rates are high even among adolescents, ${ }^{6-9}$ which has led to smoking being labeled a pediatric disease or epidemic. ${ }^{10,11}$ Approximately half of all long-term smokers die prematurely as a result of smoking, ${ }^{12}$ and the life span of the continuing smoker will be reduced by 10 years on average. ${ }^{13}$ Smoking cessation provides major health benefits to men and women of all ages. For example, people who quit smoking by 50 years of age have half the risk of dying in the next 15 years compared with continuing smokers (around 10\% versus $20 \%$ at age 50, varying by sex and amount smoked). ${ }^{14}$ 
Although it is nicotine and its psychological effects that engender addiction, ${ }^{15,16}$ it is tobacco's other components 'tar', volatile oxidant gases and carbon monoxide - that cause most of the damage to health. ${ }^{16-20}$

Nicotine replacement products are the first-line treatment for nicotine dependence approved by the US. Food and Drug Administration (FDA). Currently, there are many nicotine delivery devices available in the market - these include nicotine gum, transdermal patches, vapor inhalers, nasal spray, lozenges, and sublingual tablets. ${ }^{21}$ These treatments enhance cessation by delivering nicotine without exposure to the carcinogenic compounds found in cigarette smoke. The use of these nicotine replacement products has led to varying degrees of success in long-term smoking cessation, ${ }^{22}$ which has been reviewed extensively elsewhere..$^{22,23}$ Newer products seeking approval from the FDA include nicotine vaccines. Immunologic approaches to treating tobacco dependence have three key advantages. First, immunization appears to be safe because of its low cross-reactivity with compounds other than nicotine. Second, immunization only requires a brief series of monthly injections to produce effects that can endure for months. The lack of major side effects and relatively minimal dosing requirements could be associated with improved patient compliance. Third, its unique mechanism of action makes it well suited for combination with other pharmacotherapies.

This review focuses on recent advances that could lead to the development of therapeutic vaccines for smoking cessation.

\section{Nicotine effects}

Addiction is defined as a situation in which a drug unreasonably controls behavior. ${ }^{24-27}$ Dependence-producing drugs often cause "tolerance", physical dependence, and pleasurable effects. ${ }^{1,28-35}$

Tobacco smokers inhale over 4,000 chemicals that have possible pharmacologic and toxicologic effects. Carbon dioxide $\left(\mathrm{CO}_{2}\right)$ and nitric oxide (NO) produce vascular dilatation, whereas nicotine produces primarily vasoconstriction. ${ }^{35,36}$ Nicotine is the primary component of tobacco that is responsible for maintaining smoking addiction. ${ }^{18,19}$ Animal models demonstrate nicotine's addictive potential, ${ }^{37,38}$ and many studies have also shown nicotine's addiction in humans. ${ }^{39}$

There is evidence that nicotine from smoking can improve some types of cognitive performance and vigilance. Smokers often claim that smoking can both relieve stress and offset boredom or drowsiness. This may have its origin in the biphasic dose-related effects of nicotine, with low doses resulting in a stimulant effect, and higher doses resulting in a depressant effect. ${ }^{35}$ Moreover, nicotine can have short-term unpleasant side effects including dizziness, nicotine-induced nystagmus and nausea. These unpleasant effects appear more common in nonsmokers or light smokers than heavy smokers. ${ }^{36}$

Nicotine is a weak base containing a pyridine and a pyrrolidine ring; each one possesses a tertiary amine (Figure 1). The $\mathrm{p} K_{\mathrm{a}}$ of the pyridine nitrogen is 3.04 , whereas the $\mathrm{p} K_{\mathrm{a}}$ of the pyrrolidine nitrogen is 7.84 at physiologic temperature and ionic strength. With these characteristics, approximately $23 \%$ of nicotine is nonionized at physiologic $\mathrm{pH}$ and thus able to rapidly cross biological membranes. ${ }^{40-42}$ Smoke from tobaccos used in pipes and cigars is more alkaline ( $\mathrm{pH}=6.5$ or more), and as a result, nicotine is mostly unionized and well absorbed from the mouth. ${ }^{43}$ The plasma half-life $\left(t_{1 / 2}\right)$ of nicotine is approximately 2 hours. In the brain, the distributional $t_{1 / 2}$ of nicotine is 10 minutes. Distributional $t_{1 / 2}$ describes the time that it takes a nicotine dose to fall $50 \%$ from its peak level in the brain as the nicotine is distributed to other body compartments with a high affinity for nicotine (for example, the liver, spleen, kidney, lung). ${ }^{42,44}$ Nicotine is absorbed from smoke into the circulation relatively quickly because of the large alveolar surface and large blood perfusion of the pulmonary circulation. During smoking, high levels of nicotine reach the brain in 10-20 seconds after a puff, faster than with intravenous administration. ${ }^{42-44}$ Nicotine is extensively metabolized in the liver to six primary metabolites (nicotine glucuronide, nicotine $\mathrm{N}$-oxide, nornicotine, nicotine isomethonium ion, cotinine, 2-hydroxynicotine). The predominant pathway during first-pass metabolism yields cotinine (in humans $70 \%-80 \%$ of nicotine is metabolized to cotinine), which may

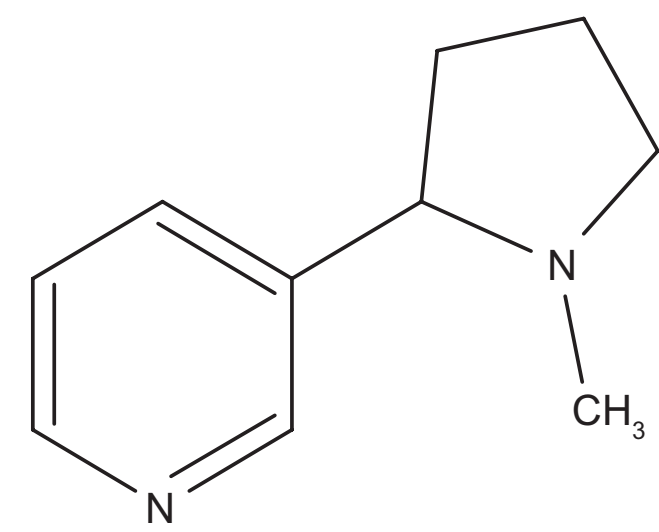

Figure I Chemical structure of nicotine (with permission Bentham Science Publishers $\left.{ }^{\oplus}\right)^{65}$ 
have some relevance in the diverse neurobiological effects of smoking as a ligand of nicotinic acetylcholine receptors (nAChRs) ${ }^{40,41}$ Unmetabolized nicotine excretion via the urine only accounts for about $5 \%$ of total elimination. The rate of nicotine metabolism is influenced by many factors, such as age, gender, food consumption, race, hepatic or renal diseases, pregnancy, and tobacco ingredients. ${ }^{17-20}$

Nicotine has a wide variety of effects on the central nervous system (CNS) which impact behavioral function..$^{20,45-49}$ After nicotine enters the body, it binds to nAChRs of the CNS, specifically those in the brain, and initiates drug addiction. Once nicotine activates the nAChRs in the CNS, dopamine is released in the nucleus accumbens, a region important for the rewarding properties of the drug. ${ }^{16,41,50}$ Nicotine alters the function of several CNS neurotransmitters, including dopamine (DA), noradrenaline (NA), 5-hydroxytryptamine (5-HT), glutamate, gamma amino butyric acid (GABA) and endogenous opioid peptides (EOPs). ${ }^{51}$ In the brain, nicotine acts via nAChRs, which are distinct members of the neurotransmitter-gated ion channel superfamily and have crucial neuromodulatory roles in the CNS. ${ }^{52,53}$ The endogenous neurotransmitter at nAChRs is ACh. ${ }^{53,54,61,62}$ Stimulation by nicotine of presynaptic nAChRs on these neurons increases neurotransmitter release and metabolism. Unlike most agonists, which downregulate the number of receptors with chronic exposure, the chronic administration of nicotine leads to desensitization and inactivation of nAChRs, and to a 'paradoxical' upregulation of nAChRs sites. After overnight abstinence, these nAChRs are likely to desensitize and are believed to be fully responsive to nicotine as an exogenous agonist. . $^{55,56}$

Chronic nicotine administration is thought to cause postreceptor changes such as changes in gene expression, and in protein synthesis and degradation in CNS neurons (such as the mesolimbic DA system), which lead to the complex processes of nicotine dependence and withdrawal. ${ }^{52}$ In addition to nicotine, tobacco contains approximately 2500 chemical compounds, while tobacco smoke consists of over 4000 chemical constituents, some of which have psychopharmacologic effects, and thus contribute to the nicotine dependence state in humans. Several compounds of smoke are generated by various mechanisms (combustion, pyrolysis, distillation) during the burning of tobacco..$^{57,58}$ Tobacco smoke has two phases, the gaseous phase and the particulate phase. The gaseous phase contains nitrogen oxide, carbon monoxide, carbon dioxide, ammonia, nitrites, alcohols, ketones (acetone, butanone), volatile sulfurcontaining compounds (hydrogen sulfide), hydrocarbons, aldehydes (formaldehyde and acetaldehyde), free radicals and other oxidants (hydrogen peroxide, superoxide anion and peroxynitrite). According to recent results, hydrogen peroxide probably has a role in airway tumorigenesis. The particulate phase contains alkaloids, water, and tar. Nicotine is the most abundant alkaloid in tobacco (accounting for $95 \%$ of the total alkaloid content).$^{59}$

\section{Smoking cessation therapies}

Smoking cessation reduces premature deaths and improves prognosis and quality of life, so extensive, randomized, double-blind, placebo-controlled clinical trials have established the efficacy and safety of nicotine replacement therapies and bupropion and varenicline in the treatment of nicotine dependence. Of these, varenicline is the most effective for smoking cessation, followed by bupropion and nicotine replacement therapies. ${ }^{60}$

Evidence-based recommendations made by a private panel of experts (which can be found in "Treating Tobacco Use and Dependence: 2008 Update"), ${ }^{61}$ include seven first-line therapies that have been approved by the US Food and Drug Administration (FDA) as smoking-cessation aids: nicotine replacement therapy, available in the form of a transdermal patch; a nasal spray; an oral inhaler; gum; a lozenge; bupropion sustained release, available as an oral tablet; and varenicline, available as an oral tablet. The guideline panel recommends clonidine and nortriptyline, which are not approved for this indication and are associated with an increased adverse-event potential, as second-line agents for smoking cessation. Clinical selection between first-line agents is considered a function of practical factors such as patient preference, time, and cost. Use of second-line agents may be considered on a case-by-case basis when first-line monotherapy or combination therapy is unsuccessful or contraindicated. ${ }^{61}$ Tables 1 and 2 summarize the nicotine and non-nicotine replacement therapies for smoking cessation.

\section{Immunological methods}

Immunization is a form of preventive medicine. Its aim is to protect individuals and communities from infectious diseases. Immunization operates like an early warning system. It prepares the body to fight against infection or immunogens. Immunization operates on the premise that once you have had a disease, you are unlikely to contract it again. ${ }^{114}$

Through injections, oral drops or scratches on the skin, the body is exposed to weakened or dead disease-producing microorganisms or to the toxins they produce. This will cause the individual to develop the same antibodies and antitoxins 
Table I Nicotine replacement therapies and their combinations

\begin{tabular}{|c|c|c|c|}
\hline Formulation & Population & Comments & Refs. \\
\hline Nicotine nasal spray & $\begin{array}{l}\sim 36 \% \text { nonwhite smokers } \\
\text { (Hispanic) }\end{array}$ & $\begin{array}{l}\text { The proportion of patients who achieved smoking cessation } \\
\text { was significantly greater with nicotine nasal spray compared } \\
\text { with the nicotine transdermal patch. May cause nose and eye } \\
\text { irritation or cough. Higher potential for addiction compared } \\
\text { with other nicotine replacement therapies. }\end{array}$ & $62-65$ \\
\hline Transdermal nicotine patches & $\begin{array}{l}\text { British, native Alaskans } \\
\text { and American Indians }\end{array}$ & $\begin{array}{l}\text { No significant findings favoring the use of nicotine } \\
\text { transdermal patches were noted between the intervention } \\
\text { and control groups. } \\
\text { Emotional symptomatology appeared in patients: affective } \\
\text { blunting; anhedonia with tiredness and lack of energy; anxiety; } \\
\text { hypersensitivity; and tension. Less potential for addiction compared } \\
\text { with gum. }\end{array}$ & $63,66,67$ \\
\hline Nicotine lozenge & American, British (UK) & $\begin{array}{l}\text { Similar results among smokers regardless of success or failure } \\
\text { of previous pharmacologic therapy. May cause mouth soreness or } \\
\text { dyspepsia. }\end{array}$ & 68,69 \\
\hline Nicotine inhaler & British, American & $\begin{array}{l}\text { Flexible dosing; mimics hand-to-mouth action of smoking; } \\
\text { few side effects. Frequent dosing necessary. May cause mouth } \\
\text { and throat Irritation. It is contraindicated for pregnancy } \\
\text { category D, cardiovascular precautions. }\end{array}$ & 63,70 \\
\hline Nicotine gum & British, American & $\begin{array}{l}\text { Quit rates were higher in specialized cessation clinics than in } \\
\text { primary care settings; higher potential for addiction than the patch. } \\
\text { Avoid in patients with dental problems or } \\
\text { temporomandibular joint syndrome. } \\
\text { Cardiovascular precautions. }\end{array}$ & $63,71,72$ \\
\hline $\begin{array}{l}\text { Transdermal nicotine patch } \\
\text { and nicotine gum }\end{array}$ & Belgian & Combination more effective than either agent alone. & 73 \\
\hline $\begin{array}{l}\text { Transdermal nicotine patch } \\
\text { and nicotine spray }\end{array}$ & Icelander & Combination more effective than either agent alone. & 74 \\
\hline $\begin{array}{l}\text { Transdermal nicotine patch } \\
\text { and nicotine inhaler }\end{array}$ & French & Combination more effective than either agent alone. & 75 \\
\hline $\begin{array}{l}\text { Group-based cognitive- } \\
\text { behavioral therapy and } \\
\text { transdermal nicotine patches }\end{array}$ & African-American, American & $\begin{array}{l}\text { The results show that } 7 \text {-day point prevalence abstinence } \\
\text { was significantly greater in the group-based cognitive- } \\
\text { behavioral therapy than the group general health education } \\
\text { at the end of counseling ( } 51 \% \text { versus } 27 \% \text { ), at } 3 \text { months } \\
\text { ( } 34 \% \text { versus } 20 \% \text { ), and at } 6 \text { months ( } 31 \% \text { versus } 14 \% \text { ). } \\
\text { Long-term quit rates could be improved by education programs. }\end{array}$ & 76,77 \\
\hline
\end{tabular}

that would have been developed if the person had actually contracted the disease, in order to fight the disease. ${ }^{115}$

Once the body has been exposed to an infection, the immune system will "recognize" a recurrence, and produce antibodies or antitoxins to destroy the infection or the immunogen. The body has to be exposed to infection once for the immune system to recognize it. This is done through immunization. ${ }^{116}$

\section{Active versus passive immunization}

Immunization against nicotine can be achieved by two methods. Active immunization (hereafter referred to as vaccination) involves repeated administration of an immunogen to the subjects being studied in order to stimulate the immune system to produce nicotine-specific antibodies. Passive immunization involves the production of antibodies in some other species (eg, rabbits) or in vitro, which are then purified and administered to the subjects being studied. Each method has advantages and disadvantages. Vaccination requires relatively few administrations (eg, one injection per month for 3 to 4 months) to produce a high serum level of antibody that persists for several months. It is also relatively inexpensive. The primary disadvantages of vaccination are the delay to achieving required antibody levels and the inability to control those levels. Passive immunization also offers several advantages, including the ability to: i) Achieve the required serum level of antibody virtually immediately, compared with the 1 to 2 months needed for vaccination; ii) control the antibody dose to study dose response relationships; and iii) examine the effects of high antibody doses that cannot be achieved with vaccination alone. The primary disadvantages of passive immunization are that 
Table 2 Non-nicotine replacement therapies and their combinations

\begin{tabular}{|c|c|c|c|}
\hline Formulation & Population & Comments & Refs. \\
\hline Varenicline & Asian & $\begin{array}{l}\text { Helps patients achieve smoking cessation by reducing } \\
\text { cravings/withdrawal symptoms and smoking satisfaction. } \\
\text { The most commonly reported adverse effects for varenicline, } \\
\text { bupropion sustained release, and placebo in the pooled } \\
\text { analysis were nausea }(28.8 \%, 9.9 \% \text {, and } 9.1 \% \text {, respectively), } \\
\text { insomnia ( } 14.2 \%, 21.5 \% \text {, and } 12.6 \%) \text {, and headache ( } 14.2 \% \text {, } \\
\text { II.I\%, and } 12.4 \%) \text {. Particular attention with patients with } \\
\text { comorbid conditions such as those with psychiatric disorders } \\
\text { and cardiovascular disease. There is no consistent evidence } \\
\text { that varenicline reduces weight gain compared with placebo. }\end{array}$ & $78-85$ \\
\hline Bupropion sustained release & African-American & $\begin{array}{l}\text { Smokers abstain at a significantly greater rate }(P<0.05) \\
\text { when using bupropion sustained release versus placebo. }\end{array}$ & 86 \\
\hline Bupropion sustained release & American & $\begin{array}{l}\text { The efficacy of bupropion has been confirmed in several } \\
\text { large studies. Its most common side effects (occurrence } \\
>1: 100 \text { ) are dry mouth, headache, nausea and insomnia } \\
\text { and its most rare side effects (occurrence }>I: 10,000 \\
\text { and }<I: 1000 \text { ) are seizure, severe hypersensitivity reaction. } \\
\text { Moreover, bupropion has been reported more effective } \\
\text { than the nicotine patch. Bupropion advantage is that it } \\
\text { reduces post-cessation weight gain ( } 0.8 \mathrm{~kg} \text { ), compared } \\
\text { with nicotine replacement therapies by } 0.5 \mathrm{~kg} \text {. }\end{array}$ & $87-91$ \\
\hline Nortriptyline & American, Brazilian & $\begin{array}{l}\text { In controlled clinical trials nortriptyline alone has shown } \\
\text { to be effective with odds ratios ranging from I.2 to } 5.5 \text {, } \\
\text { for smoking cessation in four studies, with only one study } \\
\text { lacking a statistically significant benefit. The smoking } \\
\text { cessation rates achieved with nortriptyline appear to be } \\
\text { comparable to those achieved with bupropion. Common } \\
\text { side effects reported are dry mouth, light-headedness, } \\
\text { shakiness, and blurred vision, although urinary retention, } \\
\text { constipation, sexual difficulties, and risk of seizures. }\end{array}$ & $92-96$ \\
\hline $\begin{array}{l}\text { Clonidine (can be taken orally } \\
\text { or through a transdermal patch) }\end{array}$ & American, Chinese, French & $\begin{array}{l}\text { Placebo-controlled clinical trials indicate that clonidine is } \\
\text { superior to placebo ( } 2.4 \text { and } 2.0 \text { ratios). This is comparable } \\
\text { with the efficacy of nicotine replacement therapies and } \\
\text { bupropion. It may be beneficial in female smokers. } \\
\text { Significant side effects, such as dry mouth, dizziness and } \\
\text { postural hypotension make its use less desirable. Patients } \\
\text { with a history of depression or occlusive peripheral } \\
\text { vascular disease should avoid using clonidine. }\end{array}$ & $97-99$ \\
\hline $\begin{array}{l}\text { Endogenous Opioids (EOPs) } \\
\text { - naltrexone }\end{array}$ & American & $\begin{array}{l}\text { There is conflicting evidence for the effectiveness of } \\
\text { naltrexone monotherapy for smoking cessation. }\end{array}$ & 100 \\
\hline $\begin{array}{l}\text { Naltrexone and Transdermal } \\
\text { nicotine patch }\end{array}$ & $84.3 \%$ of white American & $\begin{array}{l}\text { Treatment with low-dose naltrexone does not significantly } \\
\text { reduce weight gain or improve smoking cessation in highly } \\
\text { weight-concerned smokers. Given that this population } \\
\text { gained relatively little weight even on placebo, cognitive } \\
\text { interventions to reduce weight concerns in combination } \\
\text { with approved smoking cessation pharmacotherapy are } \\
\text { preferable. Nevertheless, there may be other sub-populations } \\
\text { of smokers at risk of substantial weight gain following } \\
\text { smoking cessation for whom the weight suppressing } \\
\text { effects of naltrexone might be of benefit. }\end{array}$ & 101 \\
\hline Naltrexone and bupropion & $\begin{array}{l}\text { White American, American, } \\
\text { non-obese adults, overweight } \\
\text { and obese adults }\end{array}$ & $\begin{array}{l}\text { Smoking cessation rates are similar to bupropion, but there } \\
\text { was a significant trend for less weight gain with the } \\
\text { combination than with placebo and monotherapy. }\end{array}$ & 102,103 \\
\hline $\begin{array}{l}\text { Naltrexone and bupropion both } \\
\text { sustained release formulations, } \\
\text { plus behavioral counseling }\end{array}$ & $\begin{array}{l}93.3 \% \text { white American with } \\
\text { overweight or obese adults }\end{array}$ & $\begin{array}{l}\text { Combination decreased nicotine use, limited nicotine } \\
\text { withdrawal symptoms, and no significant weight gain. } \\
\text { The most common adverse events were nausea, insomnia, } \\
\text { and constipation. }\end{array}$ & 104 \\
\hline
\end{tabular}


Table 2 (Continued)

\begin{tabular}{|c|c|c|c|}
\hline Formulation & Population & Comments & Refs. \\
\hline $\begin{array}{l}\text { Selective serotonin reuptake } \\
\text { inhibitors (SSRIs) } \\
\text { - fluoxetine and paroxetine }\end{array}$ & British, American & $\begin{array}{l}\text { Significant short-term effect ( } 6 \text { months). None demonstrated } \\
\text { any long-term benefit. } \\
\text { An analysis of fluoxetine trials with negative results indicated } \\
\text { some benefit in the subgroup of smokers who had a history } \\
\text { of major depression. }\end{array}$ & 105,106 \\
\hline $\begin{array}{l}\text { Selective serotonin reuptake } \\
\text { inhibitors (SSRIs) } \\
\text { Anxiolytics: } \\
\text { - buspirone } \\
\text { - diazepam } \\
\text { - meprobamate } \\
\text { - propanolol } \\
\text { - metoprolol } \\
\text { - oxprenolol } \\
\text { - ondansetron }\end{array}$ & American, British & $\begin{array}{l}\text { Buspirone does not cause physical dependence. However, } \\
\text { a placebo-controlled trial failed to support its efficacy in } \\
\text { smoking cessation. } \\
\text { Anxiolytics have been examined to aid smoking cessation, } \\
\text { finding no or unclear effects on abstinence or withdrawal } \\
\text { symptoms. }\end{array}$ & 107,108 \\
\hline Mecamylamine & American and Canadian & $\begin{array}{l}\text { Mecamylamine reduces cholinergic activity, so it was } \\
\text { hypothesized that it may reduce urges to smoke by blocking } \\
\text { the rewarding effect of nicotine, and be most effective } \\
\text { when combined with nicotine replacement therapies. } \\
\text { Mecamylamine, compared to placebo, increased the } \\
\text { number of cigarettes smoked and plasma nicotine levels. } \\
\text { Moreover, it increased smoking intensity and resulted in } \\
\text { greater plasma nicotine levels in smokers with schizophrenia } \\
\text { compared to controls. }\end{array}$ & |09-II I \\
\hline $\begin{array}{l}\text { Monoamine oxidase (MAO) } \\
\text { inhibitors: } \\
\text { - moclobemide } \\
\text { - selegiline hydrochloride }\end{array}$ & American and Canadian & $\begin{array}{l}\text { In one long term trial, moclobemide was found to have a } \\
\text { significant effect on smoking cessation at } 6 \text { months, but not } \\
\text { at I year, compared with placebo. } \\
\text { Selegiline hydrochloride was safe and well-tolerated by } \\
\text { adult cigarette smokers, but did not improve smoking } \\
\text { abstinence rates compared to placebo. A common adverse } \\
\text { effect reported for selegiline hydrochloride was dry mouth. }\end{array}$ & 112,113 \\
\hline
\end{tabular}

it requires more frequent injections to maintain required antibody levels and is more expensive than vaccination.

\section{Vaccine formulation and administration}

Nicotine is too small (molecular weight $167 \mathrm{kD}$ ) to elicit an immune response (ie, it is not immunogenic). Thus, regular tobacco users do not have antibodies against it. Nicotine is rendered immunogenic by conjugating (linking) the drug itself or a structurally related compound (a hapten) to an immunogenic carrier protein to form a complete immunogen, referred to as a conjugate vaccine. Various types of carrier proteins have been employed, including keyhole limpet hemocyanin (KLH), ${ }^{114-116}$ a 19 -residue peptide, ${ }^{117}$ recombinant cholera toxin $\mathrm{B}$ subunit, ${ }^{118}$ and recombinant pseudomonas exoprotein A. ${ }^{119}$ The latter two have the advantage of having been used previously in vaccines administered to humans. The conjugation of nicotine to a carrier protein has typically been accomplished using a linker, such as succinic acid. One vaccine in development uses virus-like particles formed from the bacteriophage $\mathrm{Qb}$ instead of a carrier protein. ${ }^{120,132}$ Most vaccines are prepared for administration by mixing the complete immunogen with an adjuvant (eg, Freund's in animals, alum in humans), which enhances the immune response. The peptide-based vaccine mentioned above does not use additional adjuvant. After the initial injection of vaccine, periodic booster doses are needed to maintain satisfactory antibody levels, since exposure to nicotine by itself does not elicit an anamnestic (booster) response. Vaccination schedules in rats typically involve 2 to 4 injections at 2 to 4 week intervals. No studies have been published directly comparing different schedules to suggest an optimal one. Vaccination schedules during early clinical trials in humans have involved 2 to 6 injections also at 2 to 4 week intervals.

\section{Specific vaccines and antibodies}

The effects of nine different nicotine vaccines have been reported in rodents, ${ }^{114-118,120-121}$ three of which have been tested in Phase I and II clinical trials. ${ }^{120,125}$ The effects of passive immunization using various forms of nicotine-specific 
antibody have also been examined in several studies in rodents. ${ }^{113,114,117,126}$ Although the formulation varies between these vaccines and antibodies, their mechanism of action is the same and their pharmacokinetic and behavioral effects in animals and humans are generally similar.

\section{Antibody characteristics}

Three characteristics of vaccines that are relevant to treating drug abuse include immunogenicity, and the affinity and specificity of the elicited antibodies. Immunogenicity refers to the serum concentration of antibody that is achieved. In order to be maximally effective, a vaccine must elicit and maintain a high serum concentration of antibody throughout the period of interest, because higher ratios of antibody to nicotine result in greater binding of nicotine in serum. Affinity refers to the strength with which the elicited antibodies bind the drug. Specificity refers to the extent to which the antibodies bind nicotine in preference to other compounds.

Greater specificity reduces competition from other compounds for binding capacity, improves safety, and reduces the likelihood of adverse side effects. Vaccine formulation can influence these three properties. For example, specificity is influenced by linker position. Linkers that are distant from prime sites of metabolism help to elicit antibodies that preferentially bind nicotine over its metabolites. ${ }^{58,117}$ In addition, immunogenicity appears to be influenced by the design of the hapten. ${ }^{120}$

All of the vaccines studied to date in animals have been sufficiently immunogenic to elicit significant concentrations of nicotine-specific antibody in serum (eg, $180-250 \mu \mathrm{g} / \mathrm{mL}){ }^{58,127}$ That bind nicotine with high affinity (eg, $\mathrm{K}_{\mathrm{d}}$ [affinity constant antigen-antibody] 37-50 nM). ${ }^{117,118}$ These antibodies also generally show high specificity for nicotine, as binding of other compounds is very low (cross-reactivity with other compounds such as nicotine metabolites, acetylcholine, or other neurotransmitters is typically less than $5 \%)^{58,59,116,118}$

\section{Vaccines against nicotine}

Vaccines against nicotine are at an advanced stage of clinical evaluation in many places, but are not yet approved for treatment of individuals.

Nicotine itself is a very small molecule (Figure 1) and is not able to induce antibodies directed against it. But it can be chemically linked to a carrier protein, which renders the nicotine molecule visible to the immune system.

Immune complexes formed in the body have a tendency to deposit and to lead to severe immune-complex induced diseases such as serum disease, Arthus reaction and immune-complex related glomerulonephritis or SanarelliShwartzman phenomenon. Treatments leading to immunecomplex deposits are dangerous for the patient.

However, nicotine is a small molecule and allows only one antibody to bind at a time. Large pathologic immune complexes can therefore not be formed, as their construction requires more than one binding site. ${ }^{128}$

The antibodies elicited by a nicotine vaccine conjugate circulate in the blood stream and bind to the nicotine as it enters the body through the lungs. After the binding of the antibody to nicotine, the nicotine-antibody complex cannot cross the blood-brain barrier due to its size. There is no nicotine-induced cerebral stimulation and for the smoker the impression is comparable to smoking a cigarette without nicotine. The vicious circle between smoking and nicotineinduced stimulation is broken. The antibodies don't have any effect on withdrawal symptoms. The craving of the smoker for nicotine is not affected but smoking can't satisfy the craving any more.

The interaction of antibodies with nicotine is a reversible interaction and each antibody releases and binds nicotine many times, the way a juggler catches and releases multiple sticks many times. This is one of the reasons that the observed binding capacity of the antibodies for nicotine is far in excess of what a simple stoichiometric calculation would let us expect. Pentel et al have observed a protective effect in a rat model under conditions where the daily nicotine dose given exceeded the calculated theoretical nicotine binding capacity of the antibodies in the animal by more than 33 times. ${ }^{119}$ In view of the reversible nature of the antibody binding to nicotine, some of the nicotine will reach the receptor. But there is a very significant delay and the dependence-inducing stimulation is based on an almost instantaneous stimulation after application.

The protective effect of the anti-nicotine vaccine in a mouse model ${ }^{129}$ has been evaluated under conditions of a continuous challenge with a very high nicotine dose, with the help of osmotic pumps which were surgically implanted under the skin. The pumps delivered $1.5 \mathrm{mg} / \mathrm{kg} /$ day of nicotine over a period of 4 weeks to each of the animals. This corresponds to the nicotine equivalent of four to five packages of cigarettes for a $70 \mathrm{~kg}$ man per day, assuming that $1 \mathrm{mg}$ nicotine is absorbed by the body per cigarette. At the end of the 4 weeks the animals were challenged with a bolus of radioactively labeled nicotine, corresponding to two cigarettes, in order to check if the vaccine was still effective. The mice were sacrificed 5 minutes later, the brain 
was extracted and the nicotine concentration in blood and brain was measured separately.

In vaccinated animals the nicotine concentration was significantly higher than in control animals as the antibodies concentrated the drug in the blood. The nicotine concentration in the brain of the vaccinated animals 5 minutes after nicotine challenge was only a fraction of the concentration in the controls, because the nicotine was retained outside the brain.

\section{Vaccines against nicotine under evaluation in clinical trials}

Three companies are at an advanced stage of clinical trials and have reported some results so far (Table 3).

All anti-nicotine vaccines in development, with the exception of the vaccine developed by Sanderson et al, ${ }^{117}$ are classical vaccine constructs made up of a an adjuvant and a nicotine carrier protein conjugate, and are administered by injection. Cytos AG uses a proprietary virus-like particle as carrier protein, whereas Nabilnc and Celtic Pharma use bacterial toxin components. The vaccine developed by Sanderson et al at the University of Nebraska uses a modified form of the complement compound C5a as its carrier compound. The adjuvants used in the clinical trials are classical adjuvants such as alum hydroxide or phosphate. The information in the public domain as far as the adjuvants are concerned is not complete and the companies may evaluate proprietary adjuvant formulations in their trials. The mode of administration of the vaccines in the clinical trials reports has been limited to injection. The three companies are regularly updating ongoing studies on their websites and in professional congresses, as well as through publications in peer-reviewed journals (www.cytos.ch, www.nabi.com, www.celticpharma.com). ${ }^{130}$ Table 4 shows the inclusion and exclusion criteria for the clinical trials of these companies.

Results of Phase I studies by NabiInc and Cytos, reported as conference abstracts, suggest that these vaccines are safe,

Table 3 Companies and countries involved in the design and development of vaccines for smoking cessation

\begin{tabular}{ll}
\hline & Country \\
\hline $\begin{array}{l}\text { Main companies } \\
\text { Cytos AGN }\end{array}$ & Switzerland \\
Nabi, Inc & United States \\
Celtic Pharma & United Kingdom \\
Other companies & \\
Chilka Ltd & British Virgin Islands \\
Scripps & San Diego, USA \\
Pharmaceutica AB & Stockholm, Sweden \\
University of Nebraska & USA \\
\hline
\end{tabular}

well tolerated, and immunogenic. ${ }^{131}$ Cytos has successfully completed a Phase I study with 40 healthy nonsmoking volunteers. So far, results of a Phase I trial by Cytos have shown no unexpected toxicities and Phase II trials have started in Switzerland (Cytos). ${ }^{132}$

Preliminary results of the Phase II study indicate that the strength of the immunologic response to the vaccine varies among individuals. Among individuals with antibody responses in the highest tertile, continuous abstinence rates were significantly higher and cigarette consumption was significantly lower than among subjects who received a placebo vaccine. Abstinence rates and cigarette consumption among subjects with antibody responses in the middle or lower tertiles were not significantly different from the placebo group. ${ }^{133}$

\section{Cytos AG, Schlieren Switzerland}

Phase I study of the anti-nicotine vaccine NIB002

Cytos's nicotine vaccine program is today partnered with Novartis AG. Cytos started in April 2003 with the clinical development of the nicotine vaccine candidate NIC002 and performed a double-blind placebo-controlled Phase I study evaluating safety, immunogenicity and tolerability of the vaccine. The study evaluated four groups of 10 healthy nonsmoking volunteers with different doses and preparations of the vaccine. All patients responded with high levels of nicotine-specific antibodies and a long lasting immune response. The antibody level showed a decline over time, as expected. Adverse effects, reported in up to half of the participants, mainly involved elevated body temperature, feeling cold and muscle ache (the injections were done intramuscularly). Those symptoms mostly disappeared within 1 day and Cytos AG concluded that the vaccine was sufficiently immunogenic and safe.

\section{Phase II study of vaccine NIB002}

The randomized, placebo-controlled double-blind study included 341 smokers. Two-thirds of the cohort received the active vaccine and one-third a placebo vaccine. All participants receiving the active vaccine and none of the control group developed nicotine specific antibodies. Five injections of $100 \mu \mathrm{g}$ of vaccine conjugate were given at monthly intervals and the participants were counseled at each visit for the first 3 months. The efficacy criteria were defined as strict abstinence from week 8 to 24 and from week 8 to 52 after beginning treatment. Self-reporting as well as biochemical markers were used for the evaluation of abstinence of smoking. The vaccine was well tolerated 
Table 4 Inclusion and exclusion criteria for the clinical trials of main companies involved in the development of smoking cessation vaccine

\begin{tabular}{|c|c|c|}
\hline Company & Inclusion criteria & Exclusion criteria \\
\hline Cytos AGN & $\begin{array}{l}\text { Participants between } 18 \text { and } 70 \text { years, to have been } \\
\text { smoking at least } 10 \text { but no more than } 40 \text { cigarettes/ } \\
\text { day for more than } 3 \text { years, and willing to quit smoking. } \\
\text { Women of childbearing age had to agree to use an } \\
\text { effective form of contraception during treatment and } \\
\text { up to } 12 \text { months after the last dose of the vaccine. }\end{array}$ & $\begin{array}{l}\text { Cardiovascular, renal, pulmonary, endocrine, or neurological } \\
\text { disorders, ulcers, skin disorders, autoimmune diseases or severe } \\
\text { allergies; behavior likely to promote HIV acquisition; an active } \\
\text { liver infectious disease; a current diagnosis or a history of major } \\
\text { depressive episodes, of panic attacks, psychosis, bipolar or } \\
\text { eating disorders; use of other smoking-cessation treatments, like } \\
\text { bupropion or nicotine replacement therapy within } 6 \text { months before } \\
\text { study enrollment or at the time of screening; pregnancy or lactation; } \\
\text { abuse of alcohol or other recreational drugs; use of a psychoactive } \\
\text { drug (excluding sleeping pills) within one month before enrollment; } \\
\text { and regular use of any non-cigarette tobacco product. }\end{array}$ \\
\hline Nabi, Inc & $\begin{array}{l}\text { Participants between } 20 \text { and } 65 \text { years, willing to } \\
\text { quit smoking. }\end{array}$ & $\begin{array}{l}\text { Cardiovascular, renal, pulmonary, endocrine, or neurological } \\
\text { disorders, not using other smoking cessation therapies for at least } \\
\text { six months before the study. }\end{array}$ \\
\hline Celtic Pharma & $\begin{array}{l}\text { Participants between } 18 \text { and } 70 \text { years, willing to } \\
\text { quit smoking. }\end{array}$ & $\begin{array}{l}\text { Cardiovascular, renal, pulmonary, hepatic, endocrine, or } \\
\text { neurological disorders, ulcers, and autoimmune diseases }\end{array}$ \\
\hline
\end{tabular}

but up to $70 \%$ of the participants reported local reactions and flu-like symptoms, which disappeared within 24 hours. No side effects were reported during the follow-up period between month 6 and 12. Six-month results were published in May 2005 and 12-month results in November of the same year. There was a subgroup of 239 patients who did not use nicotine replacement products and for whom complete antibody measurements were available at month 6 . According to the antibody levels those smokers were divided into three equal groups corresponding to low-, medium- and high-responder groups. The continuous abstinence in the high responder group after 6 and 12 months was 57\% $(P=0.004$ as compared to the placebo group) and $42 \%$ respectively. The equivalent result in the medium responder group was $32 \%$ and $21 \%$ respectively, and in the low responder group, $32 \%$ and $26 \%$, respectively. The continuous abstinence rate in the placebo group was quite high at $31 \%$ and $21 \%$. A subsequent study with healthy volunteers evaluated a dose of $300 \mathrm{mg}$ of conjugate instead of $100 \mu \mathrm{g}$ per injection. Cytos claims the higher dose induced a mean antibody level four times higher than in the initial Phase II study where $100 \mu \mathrm{g}$ were injected. The company also reported on additional study protocols where $100 \mu \mathrm{g}$ were injected five times weekly or five times bi-weekly or five times monthly. A graph with data from this study shows specific antibody titers after five weeks with the weekly immunization regime were about four times higher than the antibody levels of the monthly immunization regime after four injections. In the same presentation, the bi-weekly immunization schedule shows a slower increase in antibody levels then the weekly injections. Graphs of the results can be viewed on Cytos' website (www.cytos.ch).
Cytos has also reported on the testing of a new formulation of NIC002 with the aim of achieving better tolerability of the vaccine. The company claims the new formulation has reduced the incidence of fever from nearly $40 \%$ to almost zero and has reduced the incidence of flu-like symptoms from up to $70 \%$ to about $10 \%$. $^{132-139}$

\section{Celtic pharma holdings LP}

The initial vaccine development of Celtic Pharma's vaccine goes back to Immulogic Pharmaceutical Company's development program for a nicotine vaccine in 1997. Cantab Pharmaceuticals PLC acquired Immulogic's nicotine and cocaine vaccine program in 1999 and the company merged in 2001 with Xenova Group PLC. Celtic Pharma Holdings LP took over Xenova in 2005 and announced in April 2007 that they had obtained Investigational New Drug (IND) approval for their nicotine vaccine candidate TA-NIC.

Xenova Group PLC in the United Kingdom has already completed two Phase I/II studies involving 120 patients with Celtic Pharma's vaccine candidate. Those prior trials showed efficacy and only minor side effects.

The new Phase IIB study, which Celtic started in the United States, is a placebo-controlled double-blind study and will also evaluate the efficacy of the vaccine when current standard support treatments are given. All treatment arms receive professional counseling. The study is a multicenter trial that includes different doses of the vaccine and enrolls up to 200 patients in each of the three treatment arms. The primary endpoint of the study is the abstinence rate 6 month after the initial vaccination. ${ }^{137,139,140}$ 
Completed enrollment for the Phase IIB clinical study in the US was announced by Celtic in October 2007 after recruiting over 520 patients in 10 weeks and stated that more than half the patients had already received the seven doses of vaccine, which the study protocol calls for. The dropout rate was less than $10 \%$ and Celtic expected the results of the study in the second quarter of 2008. Like the other two companies (Cytos Biotechnology and Nabi Pharmaceuticals), Celtic has completed Phase II studies. Filing for FDA approval had been expected to follow in 2009, although Phase III study results have not yet been published for (TA-NIC vaccine). Celtic Pharma has also reported clinical trial results of an anti-cocaine vaccine. ${ }^{138-140}$ Celtic expects to obtain FDA approval in 2010 for their cocaine vaccine.

\section{Nabi Inc}

Nabi announced the successful completion of the Phase IIB trial of their anti-nicotine vaccine in November 2007. Earlier publications reporting on the development of the vaccine reported on a conjugate with Pseudomonas aeruginosa exoprotein A as a carrier protein and 3'-aminomethylnicotine as a hapten. The trial was a double-blind, placebo-controlled, dose-ranging study in preparation for the Phase III study. The trial's primary endpoint is the rate of carbon monoxide (CO)-confirmed, continuous abstinence from smoking during weeks 19-26 after first application of the vaccine. The 12-month continuous abstinence with the $400 \mu \mathrm{g}$ schedule was $16 \%$ versus $6 \%$ for the placebo group, and $14 \%$ versus $6 \%$ for the placebo group with the $200 \mu \mathrm{g}$ immunization schedule. There was a strong correlation between antibody level and continuous abstinence: the top 30\% antibody responders showed a continuous abstinence rate of almost three times the rate of the placebo group after 12 months. The vaccine was well tolerated and the vaccine group showed at each stage of the study a comparable adverse event profile to the placebo group.

Nabi reported results of an improved immunization schedule in July 2008, which was based on the $400 \mu \mathrm{g}$ dose and six applications of the vaccine. Based on this schedule $80 \%$ of the subjects achieved the target antibody level at 14 weeks, which compares to only $50 \%$ of subjects with the prior immunization schedule. Nabi announced the Phase III clinical trial would start before the end of 2008 . $^{131,141,142}$ To date, Nabi has developed antibodies produced by a single injection, which last about 1 month. Currently, they are working at designing multiple sequences to be tested in order to extend the response for several months. ${ }^{145}$

\section{Chilka Ltd and other competitors developing nicotine vaccines}

Chilka Ltd is registered in the British Virgin Islands. The company intends to initiate a combined Phase I/II clinical trial in 2011. A peptide based nicotine vaccine linking nicotine to a modified form of the complement component C5a has been developed at the University of Nebraska and may also move to clinical evaluation. ${ }^{119}$ Nicotine vaccines are also being developed at Scripps ${ }^{123,143,144}$ in San Diego, CA. Pharmaceutica AB, a Swedish company based at the Karolinska Institute in Stockholm intends to start a clinical trial with its anti-nicotine vaccine in 2011. ${ }^{146-148}$

\section{Further developments to expect}

At this stage, clinical trials are concerned with efficacy and safety, and other considerations such as ease of application and price are not the primary concern, but it seems reasonable to expect over the coming years to see a differentiation of the vaccine products for commercial use. Intramuscular injections are painful, especially if used in vaccination protocols requiring as many as six injections. It seems reasonable to expect that subcutaneous application of the vaccine will replace intramuscular application in those protocols. Nicotine enters the body through the mouth, the trachea and the lungs, which are lined with mucous surfaces containing high levels of IgA antibodies.

Lindblom et $\mathrm{al}^{147}$ have shown in a mouse model that intranasal immunization is able to elicit significant levels of antibodies and we would expect some of the future application schedules to use intranasal application forms of the vaccine.

None of the vaccine studies carried out so far has reported major side effects. Some of the studies report on minor side effects, limited in most cases to the site of injection and which are of short duration.

The incidence of reported minor site effects is getting lower as the studies proceed, which means that appropriate measures concerning the formulation and scheduling of the vaccine have been taken.

All vaccines under evaluation have been assessed as therapeutic vaccines and one may ask if a prophylactic nicotine vaccine could be envisioned. From the theoretical point of view, one would be inclined to answer in the affirmative, as the immune system is mature years before a person may consider lightening up his or her first cigarette.

But, on the other hand, it does create a dangerous precedent if one replaces education with a vaccine. Where does this stop? Hasman et $\mathrm{al}^{149}$ have argued that an anti-nicotine 
vaccine may interfere with therapeutic uses of nicotine later in life, a situation which could arise if the vaccinated person develops ulcerative colitis. The incidence of the disease in the USA is modest $(35-100$ per 100,000$)$ and nicotine is neither the only nor the preferred form of treatment. Furthermore, we would expect that nicotine will have a therapeutic efficacy, as it still arrives at the receptor. ${ }^{149}$ Marketing launch dates for these nicotine vaccines have not yet been announced. ${ }^{150}$ Phase III trials and regulatory approval typically take a long time and we would expect the first nicotine vaccines to be commercialized between 2011 and 2012.

\section{Conclusion}

Immunization against nicotine can significantly attenuate several behavioral effects of nicotine in animals that are considered relevant to tobacco dependence in humans. These findings suggest that immunologic interventions could have use in the treatment of tobacco dependence. Initial clinical trials have demonstrated that nicotine vaccines are safe and produce substantial serum levels of nicotine-specific antibody in humans. Although preliminary data from these small trials suggest that vaccination may facilitate abstinence from tobacco use, more advanced trials are needed to validate this finding. Taken together, the research to date suggests that immunologic interventions could play an important role in future treatments for tobacco dependence. The primary role of such interventions will probably be in preventing relapse in smokers who are motivated to quit. By preventing a lapse by producing positive subjective and reinforcing effects, vaccination may prevent progression to full relapse. Another potential role for immunologic interventions is in facilitating reduction of tobacco use in people who are unwilling or unable to quit. It is generally accepted that the most effective approach to treating tobacco dependence is the concurrent use of medications and behavioral therapy. Despite the significant therapeutic potential of immunologic interventions, they do not target the nonpharmacological factors that maintain tobacco dependence and will probably be maximally effective when combined with behavioral interventions that motivate abstinence from tobacco use.

\section{Disclosure}

The authors report no conflicts of interest in this work.

\section{References}

1. Muñoz RF, Lenert LL, Delucchi K, et al. Toward evidence based internet interventios: a Spanish/English Web site for international smoking cessation trials. Nicotine Tob Res. 2006;8(1):77-87.
2. Thun MJ, Apicalla LF, Henley SJ. Smoking vs other risk factors as the cause of smoking-attributable deaths: confounding in the courtroom. JAMA. 2000;284(18):706-712.

3. World Health Organization. Tobacco or Health: A Global Status Report. Geneva, Switzerland: World Health Organization; 1997.

4. Blackford AL, Yang G, Hernandez-Avila M, et al. Cotinine concentration in smokers from different countries: relationship with amount smoked and cigarette type. Cancer Epidemiol Biomarkers Prev. 2006; 15(10):1799-1804.

5. Sussman S, Dent CW. Five-year prospective prediction of self-initiated quitting of cigarette smoking of high-risk youth. Addict Behav. 2007; 32(5):1094-1098.

6. Sussman S. Effects of sixty-six adolescent tobacco use cessation trials and seventeen prospective studies of self-initiated quitting. TobInd Dis. 2002;1(1):35-81.

7. US. Department of Health and Human Services. Preventing tobacco use among young people: A report of the surgeon general. Rockville, MD: Public Health Service; 1994.

8. US. Department of Health and Human Services. Reducing tobacco use: A report of the surgeon general. Atlanta, GA: Office on Smoking and Health; 2000.

9. Panday S, Reddy SP, Ruiter RAC, Bergström E, de Vries H. Nicotine dependence and withdrawal symptoms among occasional smokers. J Adolesc Health. 2007;40(2):144-150.

10. Elders MJ, Perry CL, Eriksen MP, Giovino G. The report of the Surgeon General: preventing tobacco use among young people. Am J Public Health. 1994;84(4):543-547.

11. Peto R, Lopez AD, Boreham J. Mortality from smoking in developed countries 1950-2000. Oxford, UK: Oxford University Press; 2004.

12. Doll R, Peto R, Boreham J. Mortality in relation to smoking: 50 years' observations on male British doctors. BMJ. 2004;328:1507.

13. US Department of Health and Human Services. The Health Benefits of Smoking Cessation. Washington, DC, US: Government Printing Office; 1990.

14. US Department of Health and Human Services. The Health Consequences of Smoking: Nicotine Addiction. Washington, DC, US: GovernmentPrinting Office; 1988.

15. Royal College of Physicians. Nicotine Addiction in Britain: A Report of the Tobacco Advisory Group of the Royal College of Physicians. London: Royal College of Physicians, 2000.

16. Foulds J, Burke M, Steinberg M, Williams JM, Ziedonis DM. Advances in pharmacotherapy for tobacco dependence. Expert OpinEmerg Drugs. 2004;9(1):39-53.

17. Benowitz NL. Drug therapy. Pharmacologic aspects of cigarette smoking and nicotine addiction. N Engl J Med. 1988;319(20):1318-1330.

18. Scherer G. Smoking behavior and compensation: a review of the literature. Psychopharmacology (Berl) 1999;145(1):1-20.

19. Balfour DJ. The neurobiology of tobacco dependence: a preclinical perspective on the role of the dopamine projections to the nucleus accumbens. Nicotine Tob Res. 2004;6(6):899-912.

20. Garret BE, Rose CA, Hennigfield JE. Tobacco addiction and pharmacological interventions. Expert Opin Pharmacother. 2001;2(10): $1545-1555$.

21. Stead L, Perera R, Bullen C, Mant D, Lancaster T. Nicotine replacement therapy for smoking cessation. Cochrane Database Syst Rev. 2008;1: CD000146.

22. Frishman WH, Mitta W, Kupersmith A, Ky T. Nicotine and non-nicotine smoking cessation pharmacotherapies. Cardiol Rev. 2006;14(2): $57-73$.

23. Henningfield JE, Fant RV, Buchhalter AR, Stitzer ML. Pharmacotherapy for nicotine dependence. Cancer J Clin. 2005;55(28):1-99.

24. Tobacco Advisory Group of the Royal College of Physicians. Is nicotine a drug of addiction? Nicotine addiction in Britain. London: Royal College of Physicians of London, 2000.

25. Giovino GA, Henningfield JE, Tomar SL, Escobedo LG, Slade J. Epidemiology of tobacco use and dependence. Epidemiol Rev. 1995;17: 48-65. 
26. Benowitz NL. Nicotine addiction. Prim Care. 1999;26(61):1-63.

27. US. Department of Health and Human Services. The health consequences of smoking: nicotine addiction. Rockville, MD: Office on Smoking and Health; 1988.

28. Centers for Disease Control. Cigarette smoking among adults-United States. MMWR Morb Mortal Wkly Rep. 2001;50(40):869-873.

29. Trends in cigarette smoking among high school students-United States, 1991-2001. MMWR Morb Mortal Wkly Rep. 2002;51(19): 409-412.

30. Pallonen UE, Prochaska JO, Velicer WF, et al. Stages of acquisition and cessation for adolescent smoking: an empirical integration. Addict Behav. 1998;23(3):303-324.

31. Prokhorov AV, Hudmon KS, de Moor CA, et al. Nicotine dependence, withdrawal symptoms, and adolescents' readiness to quit smoking. Nicotine Tob Res. 2001;3(2):151-155.

32. Henningfield JE, Keenan RM. Nicotine delivery kinetics and abuse liability. J Consult Clin Psychol. 1993;61:743-750.

33. Maes HH, Sullivan PF, Bulik CM, et al. A twin study of genetic and environmental influences in tobacco initiation, regular tobacco use and nicotine dependence. Psychol Med. 2004;34(7):1251-1261.

34. Tashkin DP, Murray RP. Smoking cessation in chronic obstructive pulmonarydisease. Respiratory Med. 2009;103(7):963-974.

35. Domino E, Ni L, Xu Y, Koeppe RA, Guthrie S, Zubieta JK. Regional cerebral blood flow and plasma nicotine after smoking tobacco cigarettes. Prog Neuropsychopharmacol Biol Psychiatry. 2004;28(2):319-327.

36. Golding JF, Prosyanikova O, Flynn M, Gresty MA. The effect of smoking nicotine tobacco versus smoking deprivation on motion sickness. Auton Neurosci. 2011;160(1-2):53-58.

37. Levin ED, McClernon FJ, Rezvani AH. Nicotinic effects on cognitive function: behavioral characterization, pharmacological specification and anatomic localization. Psychopharmacology (Berl). 2006; 184(3-4):523-539.

38. Rose JE, Corrigall WA. Nicotine self-administration in animals and humans: similarities and differences. Psychopharmacology (Berl). 1997;130(11):28-40.

39. Zacny JP, Stitzer ML. Cigarette brand-switching: effects on smoke exposure and smoking behavior. J Pharmacol Exp Ther. 1988;246(2): 619-627.

40. Brewer B, Roberts A, RowellP. Short-term distribution of nicotine in the rat lung. Drug Alcohol Depend. 2004;75(2):193-198.

41. Yildiz D. Nicotine, its metabolism and an overview of its biological effects. Toxicon. 2004;43(6):619-632.

42. Dome P, Lazary J, Kalapos M, ZoltanRihmer. Smoking, nicotine and neuropsychiatric disorders. Neurosci Biobehav Rev. 2010;349(3): 295-342.

43. Metz CN, Gregersen PK, Malhotra AK. Metabolism and biochemical effects of nicotine for primary care providers. Med Clin North Am. 2004;88(6): 1399-1413.

44. Baker R, Massey E, Smith G. An overview of the effects of tobacco ingredients on smoke chemistry and toxicity. Food Chem Toxicol.2004; 42 Suppl:S53-S83.

45. Jones S, Sudweeks S, Yakel JL. Nicotinic receptors in the brain: correlating physiology with function. Trends Neurosci. 1999;22(12): $555-561$.

46. Levin ED. The role of nicotinic acetylcholine receptors in cognitive function. In: Clementi F, Gotti C, Fornasari D, Editors. Handbook of experimental pharmacology: neuronal nicotinic receptors. New York: Springer-Verlag; 2000:587-602.

47. Levin ED, Rezvani AH. Development of nicotinic drug therapy for cognitive disorders. Eur J Pharmacol. 2000;393(1-3):141-146.

48. Levin ED, Simon BB. Nicotinic acetylcholine involvement in cognitive function in animals. Psychopharmacology (Berl). 1998;138(3-4): 217-230.

49. Picciotto MR. Nicotine as a modulator of behavior: beyond the inverted U. Trends Pharmacol Sci. 2003;24:493-499.

50. Levin ED, Bencan Z, Cerutti DT. Anxiolytic effects of nicotine in Zebrafish. PhysiolBehav. 2007;90(1):54-58.
51. Picciotto MR, Caldarone BJ, King SL, Zachariou V. Nicotinic receptors in the brain: Links between molecular biology and behavior. Neuropsychopharmacology. 2000;22(5):451-465.

52. Wooltorton JR, Pidoplichko VI, Broide RS, Dani JA. Differential desensitization and distribution of nicotinic acetylcholine receptor subtypes in midbrain dopamine areas. $J$ Neurosci. 2003;23(8):3176-3185.

53. Leonard S, Bertrand D. Neuronal nicotinic receptors: from structure to function. Nicotine Tob Res. 2001;3(3):203-223.

54. Zoli M, Moretti M, Zanardi A, McIntosh JM, Clementti F, Gotti C. Identification of the nicotinic receptor subtypes expressed on dopaminergic terminals in the rat striatum. $J$ Neurosci. 2002;22(20):8785-8789.

55. Mansvelder HD, McGehee DS. Cellular and synaptic mechanisms of nicotine addiction. $J$ Neurobiol. 2002;53(4):606-617.

56. Marshall DL, Redfern PH, Wonnacott S. Presynaptic nicotinic modulation of dopamine release in the three ascending pathways studied byin vivomicrodialysis: comparison of naive and chronic nicotinetreated animals. J Neurochem. 1997;68(4):1511-1519.

57. Baker RR, Massey ED, Smith G. An overview of the effects of tobacco ingredients on smoke chemistry and toxicity. Food Chem Toxicol. 2004;42 Suppl:S53-S83.

58. Newhouse P, Potter A, Singh A. Effects of nicotinic stimulation on cognitive performance. Curr Opin Pharmacol. 2004;4(1):36-46

59. Cai J, Liu B, Lin P, Su Q. Fast analysis of nicotine related alkaloids in tobacco and cigarette smoke by megabore capillary gas chromatography. J Chromatog A. 2003;1017(1-2):187-193.

60. Eisenberg MJ, Filion KB, Yavin D, et al. Pharmacotherapies for smoking cessation: a meta-analysis of randomized controlled trials. CMAJ. 2008;179(2):135-144.

61. Fiore MC, Jaén CR, Baker TB, et al; for Rockville Md: US Dept of Health and Human Services. Treating tobacco use and dependence: 2008 Update. Clinical Practice Guideline. Public Health Service; 2008.

62. Lerman C, Kaufmann V, Rukstalis M, et al. Individualizing nicotine replacement therapy for the treatment of tobacco dependence: A randomized trial. Ann Intern Med. 2004;140(6):426-433.

63. Silagy C, Lancaster T, Stead L, Mant D, Fowler G. Nicotine replacement therapy for smoking cessation [Update appears in Cochrane Database Syst Rev 2004;3:CD000146]. Cochrane Database Syst Rev. 2002;4: CD000146.

64. Sutherland G, Stapleton JA, Russell MA, et al. Randomised controlled trial of nasal nicotine spray in smoking cessation. Lancet. 1992; 340(8815):324-329.

65. Escobar-Chávez JJ, Merino V, López-Cervantes M, Rodríguez-Cruz IM, Quintanar-Guerrero D, Ganem-Quintanar A. The use of iontophoresis in the administration of nicotine and new non-nicotine drugs through the skin for smoking cessation. Curr Drug Discov Technol. 2009; 6(3):171-185.

66. Hensel MR, Cavanagh T, Lanier AP, et al. Quit rates at one year followup of Alaska Native Medical Center Tobacco Cessation Program. Alaska Med. 1995;37(2):43-47.

67. Carton S, Le Houezec J, Lagrue G, Jouvent R. Relationships between sensation seeking and emotional symptomatology during smoking cessation with nicotine patch therapy. Addict Behav. 2000;25(5):653-662.

68. Shiffman S, Dresler CM, Hajek P, Gilburt SJ, Targett DA, Strahs KR. Efficacy of a nicotine lozenge for smoking cessation. Arch Intern Med. 2002;162:1267-1276.

69. Shiffman S, Dresler CM, Rohay JM. Successful treatment with a nicotine lozenge of smokers with prior failure in pharmacological therapy [Published correction appears in Addiction 2004;99:273]. Addiction. 2004;99(1):83-92.

70. Nielsen K, Fiore MC. Cost-benefit analysis of sustained-release bupropion, nicotine patch, or both for smoking cessation. Prev Med. 2000;30(3):209-216.

71. Benowitz NL. Drug therapy. Pharmacologic aspects of cigarette smoking and nicotine addiction. N Engl Med. 1988;319(20):1318-1330.

72. Hughes JR, Gust SW, Keenan R, Fenwick JW, Skoog K, Higgins ST. Longterm use of nicotine vs placebo gum. Arch Intern Med. 1991; 151(10):1993-1998. 
73. Kornitzer M, Boutsen M, Dramaix M, Thijs J, Gustavsson G. Combined use of nicotine patch and gum in smoking cessation: a placebocontrolled clinical trial. Prev Med. 1995;24(1):41-47.

74. Blondal T, Gudmundsson LJ, Olafsdottir I, Gustavsson G, Westin A. Nicotine nasal spray with nicotine patch for smoking cessation: randomized trial with six year follow up [Published correction appears in BMJ. 1999;318:764]. BMJ. 1999;318:285-288.

75. Bohadana A, Nilsson F, Rasmussen T, Martinet Y. Nicotine inhaler and nicotine patch as a combination therapy for smoking cessation a randomized, double-blind, placebo-controlled trial. Arch Intern Med. 2000;160:3128-3134.

76. Webb MS, de Ybarra RD, Baker EA, Reis IM, Carey MP. Cognitivebehavioral therapy to promote smoking cessation among African American smokers: a randomized clinical trial. J Consult Clin Psychol. 2010;78(1):24-33.

77. Alberg AJ, StashefskyMargalit R, Burke A, et al. The influence of offering free transdermal nicotine patches on quit rates in a local health department's smoking cessation program. Addict Behav. 2004;29(9) 1763-1778.

78. Nides M, Oncken C, Gonzales D, et al. Smoking cessation with varenicline, a selective alpha4beta 2 nicotinic receptor partial agonist: Results from a 7-week, randomized, placebo- and bupropioncontrolled trial with 1-year follow-up. Arch Intern Med. 2006;166(15): 1561-1568.

79. Oncken C, Gonzales D, Nides M, et al. Efficacy and safety of the novel selective nicotinic acetylcholine receptor partial agonist, varenicline, for smoking cessation. Arch Intern Med. 2006;166(15):1571-1577.

80. Niaura R, Hays JT, Jorenby DE, et al. The efficacy and safety of varenicline for smoking cessation using a flexible dosing strategy in adult smokers: a randomized controlled trial. Curr Med Res Opin. 2008;24(7):1931-1941.

81. Tsai ST, Cho HJ, Cheng HS, et al. A randomized, placebo-controlled trial of varenicline, a selective alpha4beta 2 nicotinic acetylcholine receptor partial agonist, as a new therapy for smoking cessation in Asian smokers. Clin Ther. 2007;29(6):1027-1039.

82. Nakamura M, Oshima A, Fujimoto Y, Maruyama N, Ishibashi T, Reeves KR. Efficacy and tolerability of varenicline, an alpha4beta2 nicotinic acetylcholine receptor partial agonist, in a 12-week, randomized, placebo-controlled, dose-response study with 40-week follow-up for smoking cessation in Japanese smokers. Clin Ther. 2007; 29(6):1040-1056.

83. Tonstad S, Tønnesen P, Hajek P, Williams KE, Billing CB, Reeves KR; for the Varenicline Phase 3 Study Group. Effect of maintenance therapy with vareniciine on smoking cessation: a randomized controlled trial. JAMA. 2006;296(1):64-71.

84. Williams KE, Reeves KR, Billing CB, Pennington AM, Gong J. A double-blind study evaluating the long-term safety of varenicline for smoking cessation. Curr Med Res Opin. 2007;23(4):793-801.

85. Daubney Garrison G, Dugan SE. Varenicline: a first-line treatment option for smoking cessation. Clin Ther. 2009;31(3):463-491.

86. Ahluwalia JS, Harris KJ, Catley D, Okuyemi KS, Mayo MS. Sustainedrelease bupropion for smoking cessation in African Americans: a randomized controlled trial. JAMA. 2002;288(4):468-474.

87. Jorenby DE, Leischow SJ, Nides MA, et al. A controlled trial of sustained release bupropion, a nicotine patch, or both for smoking cessation. N Engl J Med. 1999;340(9):685-691.

88. Hurt RD, Sachs DP, Glover ED, et al. A comparison of sustained release bupropion and placebo for smoking cessation. N Engl J Med. 1997; 337(17):1195-1202.

89. Breslau N, Kilbey M, Andreski P. Nicotine dependence, major depression, and anxiety in young adults. Arch Gen Psychiatry. 1991;48(12): 1069-1074.

90. Richmond R, Zwar N. Review of bupropion for smoking cessation. Drug Alcohol Rev. 2003;22(2):203-220.

91. Parsons AC, Shraim M, Inglis J, Aveyard P, Hajek P. Interventions for preventing weight gain after smoking cessation. Cochrane Database Syst Rev. 2009;1:CD006219.
92. Hall SM, Reus VI, Munoz RF, et al. Nortriptyline and cognitive behavioral therapy in the treatment of cigarette smoking. Arch Gen Psychiatry.1998;55(8):683-690.

93. Prochazka AV, Weaver MJ, Keller RT, Fryer GE, Licari PA, Lofaso D. A randomized trial of nortriptyline for smoking cessation. Arch Intern Med. 1998;158(18):2035-2039.

94. Hall SM, Humfleet GL, Reus VI, Munoz RF, Hartz DT, Maude-Griffin R. Psychological intervention and antidepressant treatment in smoking cessation. Arch Gen Psychiatry. 2002;59(10):930-936.

95. Da Costa CL, Younes RN, Lourenco MT. Stopping smoking: a prospective, randomized, double-blind study comparing nortriptyline to placebo. Chest. 2002;122(2):403-408.

96. Hughes JR, Stead LF, Lancaster T. Nortriptyline for smoking cessation: a review. Nicotine Tob Res. 2005;7(4):491-499.

97. Covey LS, Glassman AH. A meta-analysis of double-blind placebo controlled trials of clonidine for smoking cessation. Br JAddict. 1991; 86(8):991-998.

98. Gourlay SG, Benowitz N. Is clonidine an effective smoking cessation therapy? Drugs. 1995;50(2):197-207.

99. Gourlay SG, Stead LF, Benowitz NL. Clonidine for smoking cessation. In: The Cochrane Library, Issue 3. Chichester, UK: John Wiley \& Sons, Ltd; 2000.

100. David S, Lancaster T, Stead LF, Evins AE. Opioid antagonists for smoking cessation. Cochrane Database Syst Rev. 2006;4:CD003086.

101. Toll BA, White M, Wu R, et al. Low-dose naltrexone augmentation of nicotine replacement for smoking cessation with reduced weight gain: A randomized trial. Drug Alcohol Depend. 2010;111(3):200-206.

102. Toll BA, Leary V, Wu R, SaloveyP, Meandzija B, O’Malley SS. A preliminary investigation of naltrexone augmentation of bupropion to stop smoking with less weight gain. Addict Behav. 2008;33(1):173-179.

103. Greenway FL, Dunayevich E, Tollefson G, et al; for the NB-201 Study Group. Comparison of Combined Bupropion and Naltrexone Therapy for Obesity with Monotherapy and Placebo. J Clin Endocrinol Metab. 2009;94(12):4898-4906.

104. Wilcox CS, Oskooilar N, Erickson JS, et al. An open-label study of naltrexone and bupropion combination therapy for smoking cessation in overweight and obese subjects. Addict Behav. 2010;35(3):229-234.

105. Hughes JR, Stead LF, Lancaster T. Antidepressants for smoking cessation (Cochrane Review). In: The Cochrane Library, Issue 4. Chichester, UK: John Wiley \& Sons, Ltd; 2004.

106. Hitsman B, Pingitore R, Spring B, et al. Antidepressant pharmacotherapy helps some cigarette smokers more than others. J Consult Clin Psychol. 1999;67(4):547-554.

107. Schneider NG, Olmstead RE, Steinberg C, Sloan K, Daims RM, Brown HB. Efficacy of buspirone in smoking cessation: a placebo controlled trial. Clin Pharmacol Ther. 1996;60(5):568-575.

108. Hughes JR, Stead LF, Lancaster T. Anxiolytics and antidepressants for smoking cessation (Cochrane Review). In: The Cochrane Library, Issue 4. Chichester, UK: John Wiley \& Sons, Ltd; 2000.

109. Lancaster T, Stead LF. Mecamylamine (a nicotine antagonist) for smoking cessation. In: The Cochrane Library, Issue 2. Chichester, UK: John Wiley and Sons, Ltd; 1998.

110. Gronier B, Rasmussen K. Activation of midbrain presumed dopaminergic neurones by muscarinic cholinergic receptors: an in vivoelectrophysiological study in the rat. Br J Pharmacol. 1998;124(3): 4554-4564.

111. McKee SA, Weinberger AH, Harrison ELR, Coppola S, George TP. Effects of the nicotinic receptor antagonist mecamylamine on ad-lib smoking behavior, topography, and nicotine levels in smokers with and without schizophrenia: A preliminary study. Schizophr Res. 2009;115 (2-3):317-324.

112. George TP, Weinberger AH, Monoamine oxidase inhibition for tobacco pharmacotherapy. Clin Pharmacol Ther. 2008;83(4):619-621.

113. Berlin I, Said S, Spreux-Varoquaux O, et al. A reversible monoamine oxidase A inhibitor (moclobemide) facilitates smoking cessation and abstinence in heavy, dependent smokers. Clin Pharmacol Ther. 1995; 58(4):444-452. 
114. Hieda Y, Keyler DE, Vandevoort JT, et al. Active immunization alters the plasma nicotine concentration in rats. J Pharmacol Exp Ther. 1997; 283(3):1076-1081.

115. De Villiers SH, Lindblom N, Kalayanov G, et al. Active immunization against nicotine suppresses nicotine-induced dopamine release in the rat nucleus accumbens shell. Respiration. 2002;69(3):247-253.

116. Carrera MR, Ashley JA, Hoffman TZ, et al. Investigations using immunization to attenuate the psychoactive effects of nicotine. Bioorg Med Chem. 2004;12(3):563-570.

117. Sanderson SD, Cheruku SR, Padmanilayam MP, et al. Immunization to nicotine with a peptide-based vaccine composed of a conformationally biased agonist of $\mathrm{C} 5 \mathrm{a}$ as a molecular adjuvant. Int Immunopharmacol. 2003;3(1):137-146.

118. Cerny EH, Levy R, Mauel J, et al. Preclinical development of a vaccine "against smoking". Onkologie. 2002;25(5):406-411.

119. Pentel PR, Malin DH, Ennifar S, et al. A nicotine conjugate vaccine reduces nicotine distribution to brain and attenuates its behavioral and cardiovascular effects in rats. Pharmacol Biochem Behav. 2000;65: 191-198.

120. Maurer P, Jennings GT, Willers J, et al. A therapeutic vaccine for nicotine dependence: Preclinical efficacy, and Phase I safety and immunogenicity. Eur J Immunol. 2005;35(7):2031-2040.

121. LeSage MG, Keyler DE, Hieda Y, et al. Effects of a nicotine conjugate vaccine on the acquisition and maintenance of nicotine selfadministration in rats. Psychopharmacology (Berl). 2006;184(3-4): 409-416.

122. Meijler MM, Matsushita M, Altobell L, Wirsching P, Janda KD. A new strategy for improved nicotine vaccines using conformationally constrained haptens. J Am Chem Soc. 2003;125(24):7164-7165.

123. St Clair Roberts J, Akers CVR, Vanhinsbergh L, McKenna K, Wood DM, Jack L. Longitudinal safety and immunogenicity data of TA-NIC, a novel nicotine vaccine. Proceedings of the Ninth Annual Meeting of the Society for Research on Nicotine and Tobacco; February 19-22, 2003; New Orleans, LA. Middletown, WI: Society for Research on Nicotine and Tobacco; 2003.

124. Hatsukami D, Rennard S, Jorenby DE, et al. Safety and immunogenicity of nicotine conjugate vaccine in current smokers. Clin Pharmacol Ther. 2005;78(5):456-467.

125. Keyler DE, Roiko SA, Benlhabib E, et al. Monoclonal nicotine specific antibodies reduce nicotine distribution to brain in rats: dose and affinity-response relationships. Drug Metab Dispos. 2005;33(7): 1056-1061.

126. Maurer P, Jennings GT, Willers J, et al. A therapeutic vaccine for nicotine dependence: Preclinical efficacy, and phase I safety and Immunogenicity. Eur J Immunol. 2005;35(7):2031-2040

127. Siu EC, Tyndale RF. Non-nicotinic therapies for smoking cessation. Annu Rev Pharmacol Toxicol. 2007;47:541-564.

128. Hieda Y, Keyler DE, Ennifar S, Fattom A, Pentel PR. Vaccination against nicotine during continued nicotine administration in rats: immunogenicity of the vaccine and effects on nicotine distribution to brain. Int J Immunopharmacol. 2000;22(10):809-819.

129. DeGrandaOrive JI. When will the nicotine vaccine be ready? Arch Bronconeumol. 2005;41(1):2-4.

130. Cerny T. Anti-nicotine vaccination: where are we? Recent ResultsCancer Res. 2005;166:167-175.
131. Cornuz J, Klingler K, Mueller P, et al. A therapeutic vaccine for nicotine dependence: results of a phase I and a randomized phase II study. Presented at: American Society of Clinical Oncology; May 2005; Orlando, FL. Available at: http://www.asco.org/ac/1,1003,_12-002643 -00_18-0034-00_19-0033424,00.asp. Accessed June 16, 2005.

132. Maurer P, Bachmann MF. Vaccination against nicotine: an emerging therapy for tobacco dependence. Expert Opinion Investig Drugs. 2007; 16(11):1775-1783.

133. Heading CE. Drug evaluation: CYT-002-NicQb, a therapeutic vaccine for the treatment of nicotine addiction. Curr Opin Investig Drugs. 2007;8(1):71-77.

134. Maurer P, Bachmann MF. Therapeutic vaccines for nicotine dependence. Curr Opin Mol Ther. 2006;8:11-16.

135. Maurer P, Jennings GT, Willers J, et al. A therapeutic vaccine for nicotine dependence: preclinical efficacy, and Phase I safety and immunogenicity. Eur J Immunol. 2005;35(7):2031-2040.

136. Cornuz J, Zwahlen S, Jungi WF, et al. A vaccine against nicotine for smoking cessation: a randomized controlled trial. PLoS One. 2008; 3(6):e2547.

137. Trial watch: Xenova's TA-NIC vaccine shows promise. Expert Rev Vaccines. 2004;3(4):386.

138. Goniewicz ML, Koszowski B, Czogala J, Zymelka A. New prospects of nicotine dependence treatment - vaccines. Przeg Lek. 2006;63:1114-1118.

139. Heading CE. TA-CD. Xenova. IDrugs. 2002;5(11):1070-1074.

140. Kosten TR, Rosen M, Bond J, et al. Human therapeutic cocaine vaccine: Safety and immunogenicity. Vaccine. 2002;20(7-8):1196-1204.

141. Martell BA, Mitchell E, Poling J, Gonsai K, Kosten TR. Vaccine pharmacotherapy for the treatment of cocaine dependence. Biol Psychiatry. 2005;58(2):158-164.

142. Heading CE. NicVAX (Nabi Biopharmaceuticals). IDrugs. 2003;6(1): 1178-1181.

143. Keyler DE, Roiko SA, Earley CA, Murtaugh MP, Pentel PR. Enhanced immunogenicity of a bivalent nicotine vaccine. Int Immunopharmacol. 2008;8(11):1589-1594.

144. Meijler MM, Matsushita M, Altobell LJ, Wirsching P, Janda KD. A new strategy for improved nicotine vaccines using conformationally constrained haptens. J Am Chem Soc. 2003;125(24):7164-7165.

145. Clinical trials: NicVAX (Nicotine Conjugate Vaccine). Nabi Biopharmaceuticals website. Available at: http:/www.nabi.com/pipeline/ pipeline.php?id=3. Accessed on.

146. Dickerson TJ, Yamamoto N, Janda KD. Antibody-catalyzed oxidative degradation of nicotine using riboflavin. Bioorg Med Chem. 2004; 12(18):4981-4987.

147. Lindblom N, de Villiers SH, Kalayanov G, Gordon S, Johansson AM, Svensson TH. Active immunization against nicotine prevents reinstatement of nicotine-seeking behavior in rats. Respiration. 2002; 69(3):254-260.

148. Cerny EH, Levy R, Mauel J, et al. Preclinical development of a vaccine 'against smoking'. Onkologie. 2002;25(5):406-411.

149. Hasman A, Holm S. Nicotine conjugate vaccine: Is there a right to a smoking future? J Med Ethics. 2004;30(4):344-345.

150. Cerny T, Cerny EH. Reply to: Hasman A and Holm S. Nicotine conjugate vaccine: Is there a right to a smoking future? J Med Ethics. 2005;31(9):558
Drug Design, Development and Therapy

\section{Publish your work in this journal}

Drug Design, Development and Therapy is an international, peerreviewed open-access journal that spans the spectrum of drug design and development through to clinical applications. Clinical outcomes, patient safety, and programs for the development and effective, safe, and sustained use of medicines are a feature of the journal, which

\section{Dovepress}

has also been accepted for indexing on PubMed Central. The manuscript management system is completely online and includes a very quick and fair peer-review system, which is all easy to use. Visit http://www.dovepress.com/testimonials.php to read real quotes from published authors. 